Vol. 14, $n^{\circ} 2 \mid 2010$

Varia

\title{
Becker (Peter) and Wetzell (Richard F.), Criminals and their Scientists: The History of Criminology in
} International Perspective

Cambridge, New York, Cambridge University Press, 2006, 492 pp., ISBN 0-521-81012-4 (PB); 978-0-521-81012-8 (HB)

Anja Johansen

\section{(2) OpenEdition}

\section{Journals}

Electronic version

URL: https://journals.openedition.org/chs/1230

DOI: $10.4000 /$ chs. 1230

ISSN: $1663-4837$

Publisher

Librairie Droz

Printed version

Date of publication: 1 December 2010

Number of pages: 159-161

ISBN: 978-2-600-01470-0

ISSN: $1422-0857$

\section{Electronic reference}

Anja Johansen, "Becker (Peter) and Wetzell (Richard F.), Criminals and their Scientists: The History of Criminology in International Perspective", Crime, Histoire \& Sociétés / Crime, History \& Societies [Online] Vol. 14, n² | 2010, Online since 02 December 2010, connection on 23 March 2022. URL: http:// journals.openedition.org/chs/1230 ; DOl: https://doi.org/10.4000/chs.1230 
Becker (Peter) and Wetzell (Richard F.), Criminals and their Scientists: The History of Criminology in International Perspective, Cambridge, New York, Cambridge University Press, 2006, 492 pp., ISBN 0-521-81012-4 (PB); 978-0521-81012-8 (HB)

This collected volume of essays grew out of a conference on criminology, which took place in 1998. With a delay of eight years before the publication of the edited book, this cannot unfortunately be regarded as reflecting the current state of the research. However, the merit of this volume lies elsewhere. The collection presents a multidimensional and highly inspiring introduction to a range of themes and approaches related to $19^{\text {th }}$ century criminological thinking. Although only directly referred to in a few contributions, there seems to be an underlying theme concerning the relationship between criminological thinking of the late $19^{\text {th }}$ and early $20^{\text {th }}$ century and the infamous programs of eugenics undertaken by the Third Reich and other extreme attempts to engineer societies so as to minimise, or altogether eliminate, crime and deviance. It is therefore interesting reading not only for specialists on the rise of criminology and researchers generally interested in the history of crime and criminal justice, but also for researchers with a more general interest in the cultural and intellectual background for some of the more extreme attempts in the $20^{\text {th }}$ century to engineer individuals to conform to general social norms for acceptable behaviour.

Together the chapters do not form a coherent narrative of the origins and development of criminological discourse. This is a deliberate choice, and a good one I believe, as any attempt to present a homogenous description of $19^{\text {th }}$ century criminological thinking inevitably creates the illusion of coherency and inner logic where in fact the field is characterised by heterogeneity and much of the writing flawed by inconsistency and poor science. Instead the authors present aspects of criminological discourse in the widest possible sense including the writing of scientists, theorists, self-styled experts and media coverage. What binds the different contributions together is the concept of criminology as an ongoing discourse, tracing its different manifestations in a very Foucauldian sense (Becker \& Wetzell, pp. 1-2). While the shadow of Foucault is unmistakable in several contributions (Becker, Salvatore), 
linking criminological thinking and practice to wider agendas of control through institutionalisation, other contributors use the idea of discourse in a very loose way. The aim is not to discuss methodology or to provide a coherent or comprehensive narrative of the development of criminology in the $19^{\text {th }}$ century.

The merit of the book is to bring together researchers with a broad range of perspectives on criminology. However, the papers on the German speaking parts of Europe take a particularly prominent place. The reason for this is not apparent or explicit, but may simply be due to the fact that the original conference in Florence was sponsored by the German Historical Institute in Washington. This does give a rather unbalanced impression: eight contributions out of twenty-one (Lees, Becker, Bondio, Fritzsche, Wetzell, Liang, Finder, Giles). Indeed the final part of the book, with four contributions, is specifically concerned with the development of German criminology from the Weimar Republic to the Third Reich. By contrast, Italy is only represented by one contribution (Gibson) despite the fact that one of the running themes in the book is the reception of Lombroso. Four contributions focus on France (Renneville, Mucchielli, Kaluszynski, Artières) while only Wiener focuses on Britain. The rest of the world is represented through four contributions on the US (Rafter), Australia (Garton), Argentina (Salvatore), and Japan (Nakatani). The contributions of Berkowitz, Horn and Caplan refer broadly to major European countries.

One major theme is the reception of Lombroso's theories in countries around the world and how Lombroso's ideas were adapted, often only very selectively, to local agendas and concepts of "the criminal". Another main theme is the tension between the practitioners such as medics, prison officials and chaplains, on the one hand, and theorists on sociology and psychology the other, who saw criminal acts as a reflection of faulty social or biological development. Linked to this is the gradual institutionalisation of some approaches, while other approaches were pushed to the margins or abandoned. A third theme revolves around the institutionalisation of particular aspects of criminological knowledge as a field of expertise, before criminology emerged as a recognised academic discipline. The collection also reflects two contributions to the discussions about the opposition between French criminologist and Italian, Lombroso-inspired, criminal anthropologists in which the two contributors (Mucchielli, Kaluszynski) take opposite views on the question of French exceptionalism. Of particular interest for non-specialist readers are the contributions on the dissemination of knowledge on crime to policy makers and to the wider public.

What I miss is some reflection in the introduction about the categories of 'criminologists', 'criminology', 'criminal anthropology' (mainly used in the Lombrosean sense). Becker even distinguishes between 'criminologists' (those who theorised over the nature of the criminal) and 'Criminalists' (practitioners who worked with convicted criminals). Of course these terms were loosely and inconsistently applied during the $19^{\text {th }}$ century, often by the writers themselves. Criminology was not yet a recognised academic discipline, so theorists and practitioners came with many different backgrounds, having nothing in common other than claims to possess special insight and knowledge into the nature of criminals and how best to deal with them. While it seems a good choice to avoid a coherent narrative of criminological discourse as a succession of main thinkers on the topic, there appears to be a missed opportunity to come with some suggestions to alternative ways to establish the intellectual connection of the multifaceted approach to criminologist thinking during the 
$19^{\text {th }}$ century. The editors of this volume are in an excellent position to come up with some guiding principles. Unfortunately after reading the volume, this reader was no wiser on that crucial point.

Anja Johansen

University of Dundee a.m.johansen@dundee.ac.uk 